\title{
Amino Acids, Amino Sugars and Sugars Present in the Gell Wall of some Strains of Streptococcus pyogenes
}

\author{
By M. F. MICHEL \\ Research Laboratories, Department of Rheumatology, University Hospital, \\ Leiden, The Netherlands \\ AND H. GOODER* \\ Streptococcus Reference Laboratory, Central Public Health Laboratory, \\ Colindale Avenue, London, N.W. 9
}

(Received 5 October 1961)

\section{SUMMARY}

Hydrolysates of the cell walls of 26 strains of group A streptococci were examined by paper chromatography. In all cases lysine, glutamic acid, alanine, glucosamine, muramic acid and rhamnose were found as the principal components. The mean relative proportion of lysine:glutamic acid:alanine was $1 \cdot 1: 1: 4$. Thus even when a number of strains of a particular bacterial species was tested, there was good uniformity in the cell-wall composition. Samples of cell-wall material which remained undigested after treatment with proteolytic enzymes all contained small amounts of several amino acids. It seems probable that a small amount of polypeptide or protein remained firmly attached to the cell walls examined.

\section{INTRODUCTION}

Cummins \& Harris (1956) examined the amino acids, amino sugars and sugars present in the cell walls of a large number of bacterial strains. It appeared that the amino acids present in relatively large quantities were characteristic of the genus, while the sugars and amino sugars characterized the species within a genus. Other investigations (summarized by Cummins, 1956; Salton, 1956, 1960; Work, 1957) tended to support this conclusion. In most of these studies, however, only a few strains of any one species were tested. Little quantitative information is available about the relative amounts of the principal amino acids present in the cell walls of different organisms. The main purpose of the present work was to see whether, in a larger number of strains of a species than tested by previous workers, there was a constancy in the principal amino acids of the cell wall and in their relative molecular proportions. Salton (1953) and Cummins \& Harris (1956) commented on the presence of small quantities of many amino acids in hydrolysates of cell-wall material from group A streptococci. These workers had subjected the cell walls before hydrolysis to digestion by trypsin or by trypsin + pepsin. Schwab, Cromartie \& Roberson (1959) reported that papain was more effective than trypsin, chymotrypsin, or pepsin, in that it removed a greater proportion of nitrogen-containing

* Present address: Department of Bacteriology, School of Medicine, University of North. Carolina, Chapel Hill, North Carolina, U.S.A. 
substances from such cell-wall material. Accordingly, a comparison was made of the amino acids present in small amount in samples of cell-wall preparations of group A streptococci which had been treated with different proteolytic enzymes.

\section{METHODS}

Organisms. Strains of group A streptococci were selected from stocks held at the Streptococcus Reference Laboratory (Colindale, London) and at the Department of Rheumatology, the University Hospital, Leiden, Netherlands. The designation or origin of the strains were as follows (the NCTC number is given for those strains which are included in the National Collection of Type Cultures, Colindale, England): strains carrying an M antigen: types 1 (NCTC 8198), 2 (NCTC 8322), 3 (NCTC 9994), 4. (NCTC 8326) 5, 8 (NCTC 8324), 9, 11, 12, 14, 17 (NCTC 8304), 23 (NCTC 8301), 24. (NCTC 8305), 25, 27, 30. The type strain 12 was isolated from a case of nephritis. Strains identified by the presence of T antigen: types 2 (NCTC 8322, glossy), 3/13, 5/27; a strain-carrying type $12 \mathrm{M}$ antigen and a type $10 \mathrm{~T}$ antigen (designated 12/10); a strain-carrying type $14 \mathrm{M}$ antigen alone (14/Lowe, NCTC 8199) and a variant of this strain carrying both type 14 and type 51 $\mathrm{M}$ antigens (designated 14/51, Wiley \& Wilson, 1961); strains AED (type 12 T antigen), GL 8 (type $19 \mathrm{M}$ ), ADA (type 14 M) obtained from Dr L. Dienes (Boston U.S.A.) and strains B6 (typing pattern 11/27/44) isolated locally in Leiden, Netherlands. As controls, two strains of group $\mathrm{C}$ streptococci, one of human origin and carrying a $\mathbf{T}$ antigen demonstrated by type 2 T antiserum (C/2T) and the other of animal origin (C anim) and a group $\mathrm{E}$ streptococcus, were analysed.

Isolation of cell walls. All the strains were grown for $48 \mathrm{hr}$. at $37^{\circ}$ in $2 \mathrm{l}$. of Oxoid Nutrient Broth. The cultures were checked for purity, centrifuged, the organisms washed twice with $100 \mathrm{ml}$. distilled water and finally resuspended in $25 \mathrm{ml}$. distilled water. A $1 \mathrm{ml}$. sample was removed and the weight of organisms dried over $\mathrm{P}_{2} \mathrm{O}_{5}$ was determined. Volumes $(6 \mathrm{ml}$.) of suspension were then mixed with an equal volume of ballotini beads (grade 12) in the cup of a Mickle (1948) disintegrator. Tributyl phosphate (0.04 ml.) was added to prevent frothing. After $30 \mathrm{~min}$. disintegration a smear of the disrupted organisms was stained by the Gram method. In most instances a high degree of cell breakage was observed microscopically; intact Gram-positive cocci were rarely seen. Occasionally it was necessary to continue the disruptive procedure for a further $15-30 \mathrm{~min}$. After completion of the disintegration, the cell-wall suspension was decanted from the beads; these were then washed twice in $6 \mathrm{ml}$. distilled water. The cell walls were sedimented from the combined suspensions and washings, at $10,000 \mathrm{rev} / \mathrm{min}$. $(11,730 \mathrm{~g})$ for $30 \mathrm{~min}$. and washed twice in distilled water. A sample of insoluble cell-wall material was removed and the dry weight determined. The yields of streptococci from the different strains were in the range of $135-687 \mathrm{mg} . / 2 \mathrm{l}$. culture, with a mean value of $412 \mathrm{mg}$. The yield of insoluble cell-wall material represented about $26 \%$ of the dry weight of the streptococci.

In a separate investigation strain AED was grown in 61 . of 'Todd-Hewitt broth (Difco) for $24 \mathrm{hr}$. at $37^{\circ}$. The cell walls were isolated as before, except that the streptococci were washed more thoroughly with distilled water ( 5 times) and the sedimented walls washed 5 times with distilled water, once in saline and once in $0 \cdot 05 \mathrm{M}$-phosphate buffer ( $\mathrm{pH} \mathrm{7 \cdot 8}$ ). At each stage in the washing procedure the lower 
dark-coloured layer was discarded. The sedimented material retained at each stage was examined by phase contrast and electron microscopy. In the final preparation no intact organisms were seen.

Enzyme treatment of the isolated cell walls. The isolated cell-wall preparations obtained from all the streptococcal strains were resuspended in $25 \mathrm{ml}$. 0.1 Mphosphate buffer ( $\mathrm{pH} 7 \cdot 8$ ) and after the addition of crystalline ribonuclease (1 $\mathbf{~ m g . /}$ ml.) incubated for $3 \mathrm{hr}$. at $37^{\circ}$. Then crystalline trypsin $(1 \mathrm{mg} . / \mathrm{ml}$.) was added and the incubation continued for a further $3 \mathrm{hr}$. The insoluble material remaining after digestion was sedimented in a high-speed centrifuge $30 \mathrm{~min}$. at $22,500 \mathrm{~g}$, washed three times with distilled water and dried over $\mathrm{P}_{2} \mathrm{O}_{5}$ in vacuo. Before drying, the cell-wall preparation obtained from the separate investigation with strain AED was divided into three portions; one portion was immediately dried over $\mathbf{P}_{2} \mathrm{O}_{5}$, the other two portions were subjected to digestion with pepsin or papain for 17 and $5 \mathrm{hr}$., respectively, in the appropriate buffer solution. After this further digestion the samples were washed and dried over $\mathbf{P}_{2} \mathrm{O}_{5}$.

Hydrolysis conditions. For chromatographic analysis of the amino acids and amino sugars $7.5 \mathrm{mg}$. dry weight of the wall material of each strain were heated with $5 \mathrm{ml} .6 \mathrm{~N}-\mathrm{HCl}$ in sealed tubes at $108^{\circ}$ for $16 \mathrm{hr}$. After cooling, the contents of the tubes were transferred to small Petri dishes. The hydrolysates were then taken to dryness on a steam bath to remove $\mathrm{HCl}$, redissolved in a small amount of water, filtered to remove humin, dried twice over $\mathrm{NaOH}$ in vacuo and finally dissolved in $0.4 \mathrm{ml}$. distilled water and stored frozen. For the chromatographic analysis of sugars $20 \mathrm{mg}$. dry weight of the wall material from each strain were heated with $2 \mathrm{ml} .0 \cdot 5 \mathrm{~N}-\mathrm{H}_{2} \mathrm{SO}_{4}$ in a sealed tube at $100^{\circ}$ for $2 \mathrm{hr}$. After cooling, the hydrolysates were neutralized with a saturated solution of $\mathrm{Ba}(\mathrm{OH})_{2}$, centrifuged and the sediment washed twice. The original supernatant fluid and the washings were mixed, dried over $\mathrm{P}_{2} \mathrm{O}_{5}$ in vacuo, dissolved in $\mathbf{0 . 2 5} \mathrm{ml}$. distilled water and stored frozen.

Chromatography. Amino acids, amino sugars and sugars were separated by twodimensional descending chromatography on Whatman no. 1 paper $(40 \times 30 \mathrm{~cm}$. $)$. $n$-Butanol + acetic acid + water $(60+10+20$ by vol.) and 2/4-2/5 lutidine (British Drug Houses, Ltd.) + water $(65+35$ by vol.) were used as solvents, each developed for $20 \mathrm{hr}$. For the detection of amino acids and amino sugars 0.01 and $0.02 \mathrm{ml}$, respectively, of the appropriate hydrolysates were placed on the papers. After drying of the chromatograms, amino acids and amino sugars were developed with ninhydrin and the sugars with aniline hydrogen phthalate (Partridge, 1949). The latter reagent also revealed the presence of amino sugars and $N$-acetylamino sugars. The identity of most of the spots was established by using as markers pure substances subjected to the same chromatographic conditions, separately and after admixture with the unknown sample.

Quantitative estimations of lysine, glutamic acid and alanine were performed according to the method of Kay, Harris \& Entenman (1956). Duplicate chromatograms were developed from $6 \mu \mathrm{l}$. samples of hydrolysate. The percentage standard deviation of the mean values for known quantities of lysine, glutamic acid and alanine were $\pm 5 \cdot 7, \pm 5 \cdot 9$ and $\pm 3 \%$, respectively. The results are expressed as relative molecular ratios, taking the value for glutamic acid as one unit. 


\section{RESULTS}

Amino acids and amino sugars. All the cell-wall hydrolysates of the strains tested contained lysine, glutamic acid, alanine, glucosamine and muramic acid; this finding is in keeping with other reports (Cummins \& Harris, 1956). When it was seen that in addition to these amino acids a few other ninhydrin-positive minor spots were also present on some of the paper chromatograms, several hydrolysates were retested with three times as much material applied to the chromatograms. These chromatograms gave a pattern in which eight out of the eleven minor spots were identified as glycine, serine, aspartic acid, arginine, cysteine, threonine, valine, leucine and/or isoleucine. The identity of the remaining spots was not established. The number of additional minor spots differed with different strains.

Table 1. Relative molecular ratios of the three principal amino acids present in the cell roalls of some streptococci

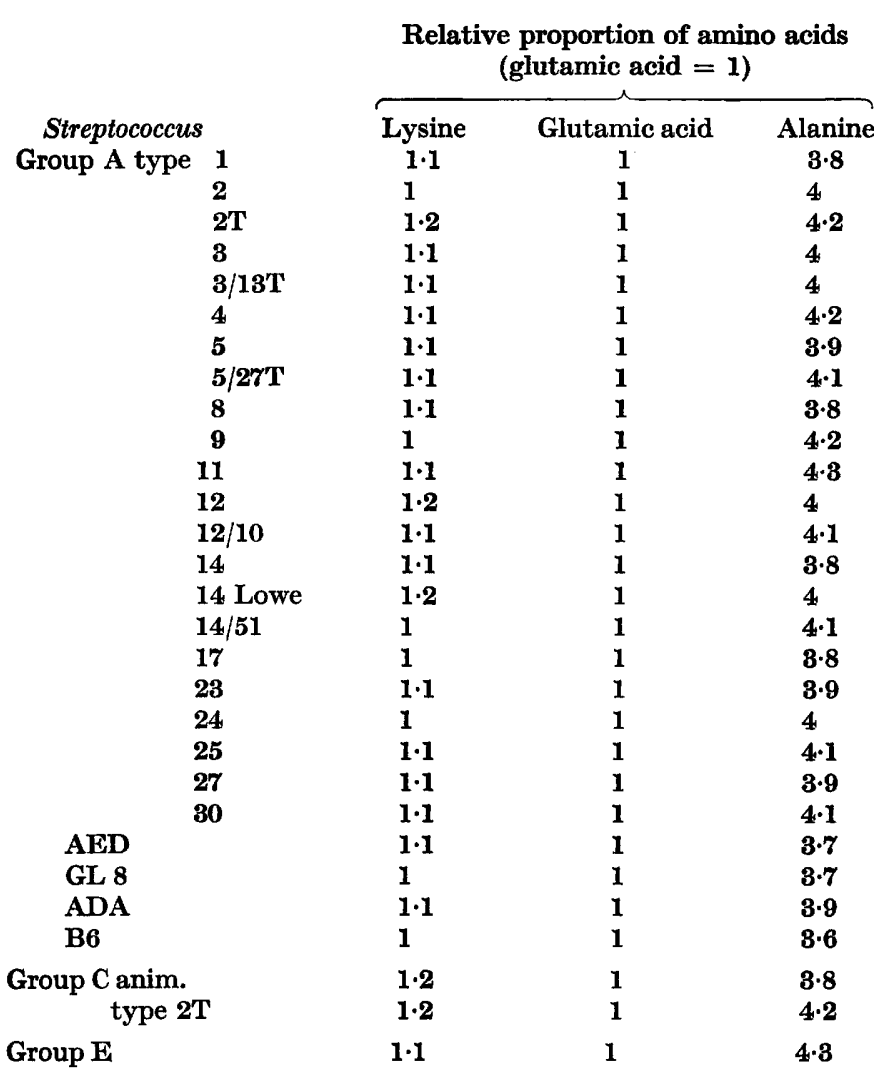

During the initial isolation of the separate samples of the cell wall of strain AED (see methods) it appeared that little of the cytoplasmic material which contaminated the cell walls was removed. However, after treatment with ribonuclease and trypsin, the material was purified to such a degree that further treatment with pepsin or papain did not influence the appearance of the cell-wall preparations in the electron 
microscope. The chromatographic pattern of the hydrolysates of the three different enzyme-treated portions of the cell-wall preparations of strain AED was indistinguishable from that obtained with other strains. Arginine was absent from all chromatograms of strain AED in both preparations.

Hydrolysates $(6 \mu \mathrm{l}$.) of group $\mathrm{C}$ and group $\mathrm{E}$ streptococci showed the same pattern of major components as that of group A streptococci except that a spot corresponding to galactosamine was found in both group $\mathrm{C}$ strains. No efforts were made to identify the additional minor amino acid components in these hydrolysates.

The relative molecular ratio of lysine, glutamic acid and alanine in the cell-wall hydrolysates from the strains examined is given in Table 1. The mean ratios for the 26 strains of group A streptococci examined were 1.1:1:4. The number of group C strains examined was too small to permit conclusions to be drawn about the relative lysine contents of their cell walls.

Sugars. The chromatograms for the sugars present in the cell-wall hydrolysates of the 26 strains of group A streptococci showed three distinct spots corresponding to rhamnose, glucosamine and $N$-acetylglucosamine. Glucosamine was reported to be present in cell walls in its acetylated form by McCarty (1952). The relatively mild conditions of hydrolysis used here for the detection of sugars would explain why glucosamine was found partly in its original form. The group $\mathrm{C}$ and group $\mathrm{E}$ strains showed spots corresponding to glucose, and to glucose and mannose, respectively. The absence of the muramic acid spot from these chromatograms and also of the galactosamine spot from both group $\mathrm{C}$ strains was probably related to the insensitivity of their reactions with alanine hydrogen phthalate.

\section{DISCUSSION}

The results reported here about the amino acids, amino sugars and sugars in the cell walls of 26 strains of group A streptococci suggest an uniformity in the major components of the cell walls. Final judgement will be possible only when information is available about the amounts of all the components. The information about the relative molecular ratios of the principal amino acids argues however in favour of the uniformity of the cell-wall composition of group A streptococci. Other unidentified components of the basal streptococcal cell wall probably exist. For example, polyolphosphates have been demonstrated in the cell walls of several bacterial species (Armstrong et al. 1959; Ikawa, 1961). It is not yet known whether these components occur in group A streptococci. Hayashi \& Barkulis (1959) reported the following composition of the cell wall of group A streptococci : amino acids $53 \%$, hexosamines $24 \%$, rhamnose $22 \%$. On the basis of these figures and taking into account the low phosphorus content of the cell wall of group A streptococci (0.7$0.8 \%$; McCarty, 1952), it seems that little space is left for teichoic acids as major cell-wall components.

Despite the general similarity of the cell-wall structure of the strains here examined, several strains have been recognized which have certain peculiarities. Roberts \& Stewart (1961) described one strain of group A streptococci which in addition to rhamnose contained glucose and galactose in the cell wall; this pattern is usually found only in group D and group $E$ streptococci. One of us (H.G.) recently investigated an unusual bile-tolerant non-haemolytic streptococcus which 
carries group A polysaccharide hapten in its cell wall. Chromatographic analysis of the sugar components present in enzyme-treated cell-wall preparations revealed glucose in addition to rhamnose. Quantitative variation in the composition of group A streptococcal cell walls is known. McCarty \& Lancefield (1955) analysed the cell wall of a strain of this species which had lost group specificity after repeated mouse passage. In consequence of a decrease in the glucosamine content of the C polysaccharide, the ratio of rhamnose to glucosamine in the cell wall in this variant was $4 \cdot 8-6$, whereas the same ratio in the parent strain was $1 \cdot 5-2$. Nevertheless, even when these minor quantitative and qualitative differences are considered it appears that the major components of the cell walls of Streptococcus pyogenes strains are a reliable guide to the taxonomic homogeneity of this group of organisms. The original suggestion of Cummins \& Harris (1956) that a study of cell-wall composition among micro-organisms might have taxonomic significance is supported by the present work. It is interesting that the hydrolysates of cell-wall material, purified in different ways, always contained small amounts of many amino acids. This suggests that a polypeptide resistant to the action of proteolytic enzymes is firmly attached to the basal cell wall. Such a polypeptide may be related to the streptococcal $\mathbf{T}$ antigen normally found on the cell wall. Trypsin digestion of whole streptococci is effective in releasing $T$ antigen from some, though not all strains of streptococci (Lancefield, 1954). The isolated $T$ antigen of type 1 streptococci is resistant to proteolytic digestion (Lancefield \& Dole,1946). Differences in the retention of $\mathbf{T}$ antigen on the samples of cell walls studied in the present work may have occurred. Ikawa (1961) reported the presence of protein in the cell walls of three other species of Gram-positive bacteria; this protein was resistant to digestion by proteolytic enzymes and represented $6 \cdot 5-9 \%$ of the dry weight of cell wall.

The muramic acid used was a gift received from Dr H. R. Perkins. We thank Miss K. Suckling and Mr H. Radema for technical assistance. One of us (M.F.M.) is indebted to the Netherlands Organization for the Advancement of Pure Research (Z.W.O.) for financial support during part of these studies.

\section{REFERENCES}

Armstrong, J. J., Baddiley, J., Buchanan, J. G., Davison, A. L., Kelemen, M. V. $\&$ NeuhaUs, F. C. (1959). Composition of teichoic acids from a number of bacterial walls. Nature, Lond. 184, 247.

Cummins, C. S. (1956). The chemical composition of the bacterial cell wall. Int. Rev. Cytol. $5,25$.

Cummins, C. S. \& Harris, H. (1956). The chemical composition of the cell wall in some Gram-positive bacteria and its possible value as a taxonomic character. J.gen. Microbiol. 14, 583.

Hayashi, J. A. \& Barkulis, S. S. (1959). Studies of streptococcal cell walls. III. The amino acids of trypsin-treated cell wall. J. Bact. 77, 177.

IKaWA, M. (1961). The partial chemical degradation of the cell walls of Lactobacillus plantarum, Streptococcus faecalis, and Lactobacillus casei. J. biol. Chem. 236, 1087.

Kay, R. E., Harris, D. C. \& Entenman, C. (1956). Quantification of the ninhydrin color reaction as applied to paper chromatography. Arch. biochem. biophys. 63, 14.

LANCEFIELd, R. C. (1954). Cellular constituents of group A streptococei concerned in antigenicity and virulence. In Streptococcal Infections, p. 3. Ed. by M. McCarty. New York: Columbia University Press. 
Lancefield, R. C. \& Dole, V. P. (1946). The properties of T antigens extracted from group A streptococci. J. exp. Med. 84, 449.

MCCARTy, M. (1952). The lysis of group A hemolytic streptococci by extracellular enzymes of Streptomyces albus II. Nature of the cellular substrate attacked by the lytic enzymes. J. exp. Med. 96, 569.

McCarty, M. \& LANCEField, R. C. (1955). Variations in the group specific carbohydrates of group A streptococci. I. Immunochemical studies on the carbohydrate of variant strains. J. exp. Med. 102, 11.

Mrckle, H. (1948). Tissue disintegrator. J. R. micr. Soc. 68, 10.

Partridge, S. M. (1949). Aniline hydrogen phthalate as a spraying reagent for chromatography of sugars. Nature, Lond. 164, 443.

Roberts, W. S. L. \& STEWART, F. S. (1961). The sugar composition of streptococeal cell walls and its relation to haemagglutination pattern. J. gen. Microbiol. 24, 253.

Salton, M. R. J. (1953). Studies of the bacterial cell wall. IV. The composition of the cell walls of some gram-positive and gram-negative bacteria. Biochim. biophys. Acta, 10, 512.

SALton, M. R. J. (1956). Bacterial cell walls. Symp. Soc. gen. Microbiol. 6, 81.

Salton, M. R. J. (1960). Surface layers of the bacterial cell. In The Bacteria, Vol. I, p. 97. Edited by I. C. Gunsalus and R. Y. Stanier. New York and London: Academic Press.

Schwab, J. H., Cromartie, W. J. \& Roberson, B. S. (1959). Identification of a toxic cellular component of group A streptococei as a complex of specific C polysaccharide and a protein. J. exp. Med. 109, 43.

WILEY, G. G. \& Wirson, A. T. (1961). The occurrence of two M antigens in certain group A streptococci related to type 14. J. exp. Med. 113, 451.

Work, E. (1957). Biochemistry of the bacterial cell wall. Nature, Lond. 179, 841. 
